\title{
Estimation of the tectonic slip-rate from Quaternary lacustrine facies within the intraplate Albacete province (SE of Spain)
}

\author{
M.A. Rodríguez-Pascua ${ }^{a}{ }{ }$, J. Bischoff $^{b}$, V.H. Garduño-Monroy ${ }^{c}$, R. Pérez-López ${ }^{a}$, J.L. Giner-Robles ${ }^{d}$,

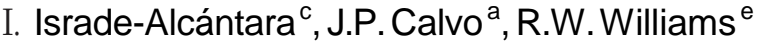 \\ a Instituto Geológico y Minero de España, C/ Ríos Rosas, 23, 28003, Madrid, Spain \\ b United States Geological Survey, 345 Middlefield Road, MS 211, Menlo Park, CA 94025, USA \\ c Universidad Michoacana, Morelia, Michoacán, 58060, Mexico \\ d Universidad Autonoma de Madrid, Facultad de Ciencias, Campus Cantoblanco, Madrid, Spain \\ e Lawrence Livermore National Lab, Livermore, CA 94551, USA
}

\begin{abstract}
The Quaternary lacustrine basin of Cordovilla (CB) represents one of the most active tectonic areas of the Prebetic Zone (Albacete, SE of Spain). The Quaternary sedimentary deposits of this basin are mainly endoreic lacustrine carbonate and alluvial deposits, developed in asemi-arid climate (Pleistocene-present). Thebasin is a NW-SE-elongated graben bounded by a major right-lateral oblique-fault, the Pozohondo Fault. This fault trends NW-SE, with an approximate trace of $55 \mathrm{~km}$, and is composed of various segments which are identified by fault scarps. In order to establish the slip-rate of the most active segment of the Pozohondo Fault, called the Cordovilla segment, we carried out a detailed study of the affected Quaternary lacustrine deposits. We found that the lacustrine facies could be related to episodic moderate paleoearthquakes. The slip-rate is calculated to be 0.05 and $0.09 \mathrm{~mm} / \mathrm{yr}$, using radiometric dating for the vertical offsets of the lacustrine facies. A trenching study at the northern part of the Cordovilla segment revealed two events caused by paleoearthquakes, with the most recent expressed as an oblique-fault off-setting a poorly-developed soil. The magnitude of the last event was greater than 6 , using various empirical relationships for the fault displacement and the surface-length rupture. We estimate episodic activity across the Cordovilla segment, to be characterized by moderate-sized paleoearthquakes (M6), which is in agreement with the tectonic context of an intraplate zone of the Iberian plate.
\end{abstract}

Keywords: Lacustrine record Quaternary fault Slip rate Intraplate Paleoearthquake

1. Introduction and geologic setting

The sedimentary record of lacustrine basins bounded by active faults represents a powerful tool for determining the slip-rate of these active faults and magnitude of the related-earthquakes for areas where both the instrumental seismic and the paleoseismic records are scarce (e.g. Schnellmann et al., 2002; Israde-Alcántara et al., 2005; Carrillo et al., 2008). In this respect, the lacustrine basin of Cordovilla (CB) (Albacete province, SE of Spain) represents a good example of the relationship between active tectonics and the dynamics of sedimentation, showing the latest fault movement affecting the Quaternary lacustrine sedimentary record.

The basin is located in the south of the province of Albacete (Fig. 1) in southern Spain. This zone basically consists of a well-preserved Tertiary

\footnotetext{
* Corresponding author.

E-mail addresses: ma.rodriguez@igme.es (M.A. Rodríguez-Pascua), jbischoff@usgs.gov (J. Bischoff),vgmonroy@umich.mx (V.H. Garduño-Monroy), r.perez@igme.es (R. Pérez-López), jlginer@gmail.com (J.L. Giner-Robles).
}

lacustrine succession (Calvo et al., 1998) and Quaternary fluvial and lacustrine strata, both overlying the Mesozoic carbonate basement (see Jérez-Mir, 1973 for the detailed description). During the Late Miocene, various continental basins $\left(\mathrm{b} 50 \mathrm{~km}^{2}\right.$ ), including the Cordovilla Basin (CB), developed at the boundary between the Iberian Cordillera (NWSE trending structures) and the northeastern part of the Betic Cordillera (SW-NE trending structures), the so-called Prebetic Zone (Sanz de Galdeano and Vera, 1992) (Fig. 1). A regional uplift of the area occurred during the Alpine Orogeny, mainly controlled by NW-SE-trending, dextral strike-slip faults with a normal component, producing the Socovos-Calasparra, Liétor, and Pozohondo Faults (Fig. 1). These faults record neotectonic evidence and recent activity shown by off-setting Quaternary deposits (García del Cura et al., 1979; Rodríguez-Pascua et al., 2008).

The tectonic evolution of $\mathrm{CB}$ is determined specifically by the Pozohondo Fault (Rodríguez-Pascua et al., 2003). A NW-SE elongated Quaternary graben basin was generated from this fault activity, developing small closed lakes (c.a. $0.03 \mathrm{~km}^{2}$ ) (Rodríguez-Pascua et al., 2008). This graben shows a complex geometry, as discussed by McCalpin (1996). This complexity is defined by various surface 


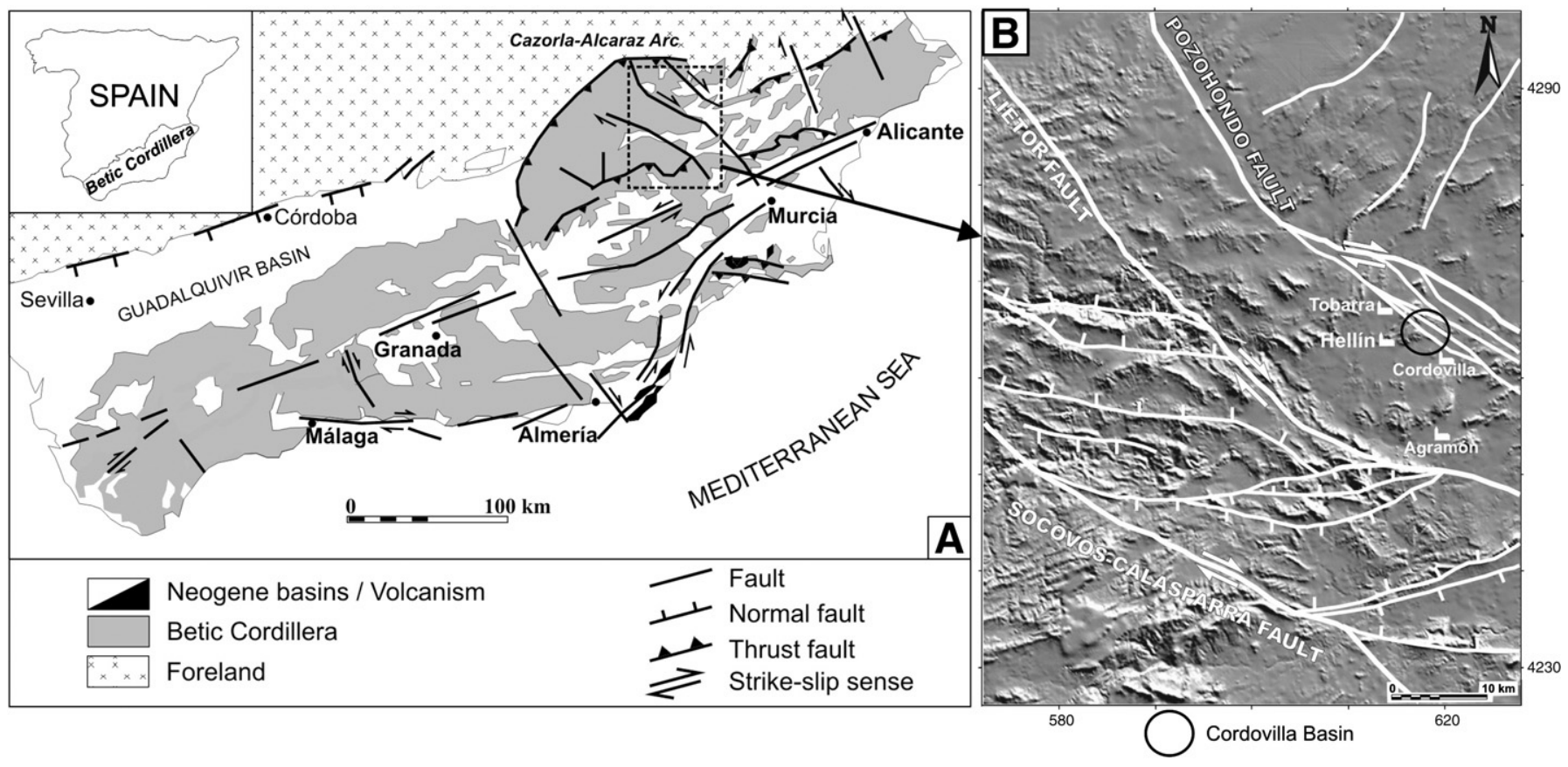

Fig. 1. Tectonic context of the area. (A) Sketch map with the geographical location of the Prebetic Zone (Betic Cordillera); boxed area encloses the region shown in panel B. (B) Tectonic framework and principal strike-slip faults of the Cordovilla Basin. This work is focused on the anastomosed SE structures of the Pozohondo Fault, the Cordovilla segment.

ruptures (the Cordovilla segment) showing collapsed alluvial plain sediments and lakebeds associated with the movements of the fault. A small central horst with lakebeds also exhibits deformation as the result of back-tilting of the antithetic fault, probably caused by accumulated paleoearthquakes. The back-tilting is defined by episodic successive movements of the antithetic fault plane. These movements generated a tilted bottom of the basin in a similar way described by McCalpin (1996). Furthermore, the Cordovilla segment exhibits a well-preserved, antithetic fault scarp affecting unconsolidated sediments, dated between 1 and 2 kyr by using the diffusion equation for the scarp degradation (Rodríguez-Pascua et al., 2008).
Both the historic and instrumental seismic records are scarce for the province of Albacete (Rodriguez de la Torre, 1992; Stitch et al., 2003) despite the Betic Cordillera being one of the most seismically active terrains of the Iberian Peninsula (e.g. Martínez-Díaz et al., 2003; Stitch et al., 2003). The geologic evidence of recent tectonic activity, noted by García del Cura et al. (1979) and Rodríguez-Pascua et al. (2008), suggests an episodic fault activity within the area, namely Holocene activity affecting the Pozohondo Fault, a NW-SE-oriented, right-lateral oblique fault with almost $55 \mathrm{~km}$ of trace. The main objective of this present work is to establish the tectonic slip-rate for the Cordovilla active segment of the Pozohondo Fault. With this aim,

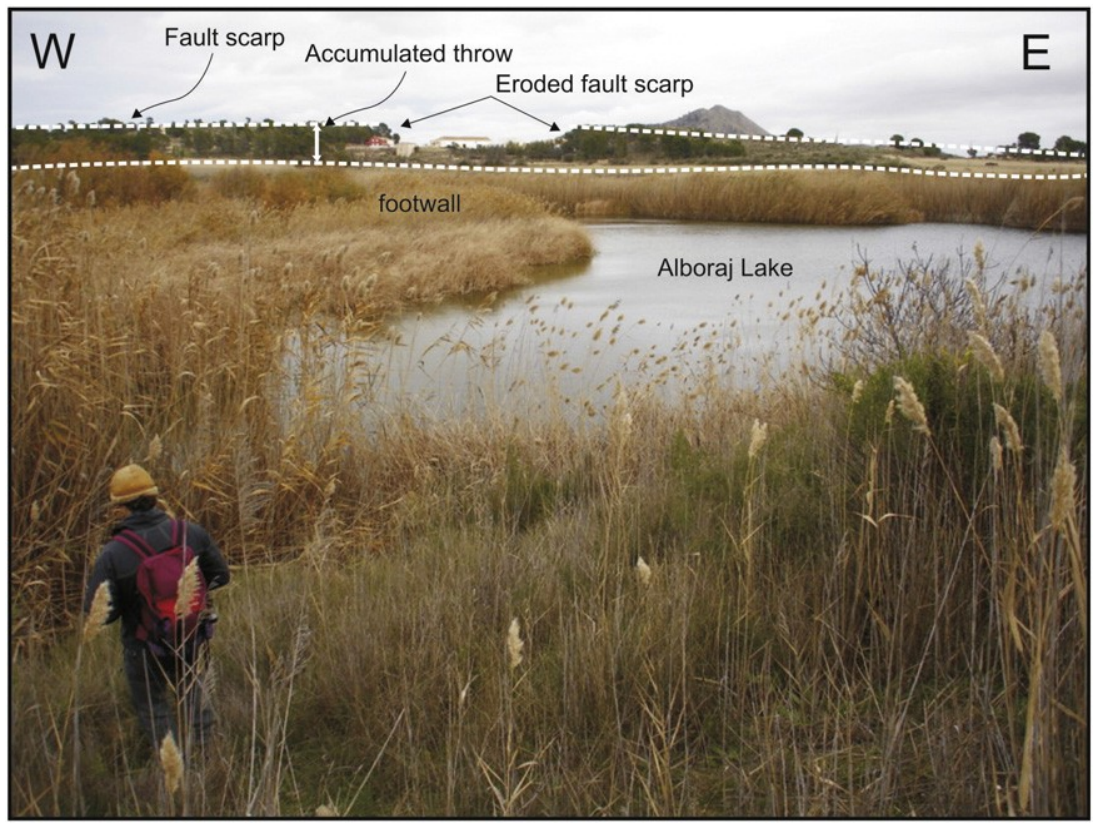

Fig. 2. Landscape view of the Alboraj Lake and northern view of the main fault scarp showing the accumulated throw and the border of the Cordovilla Basin (CB). 


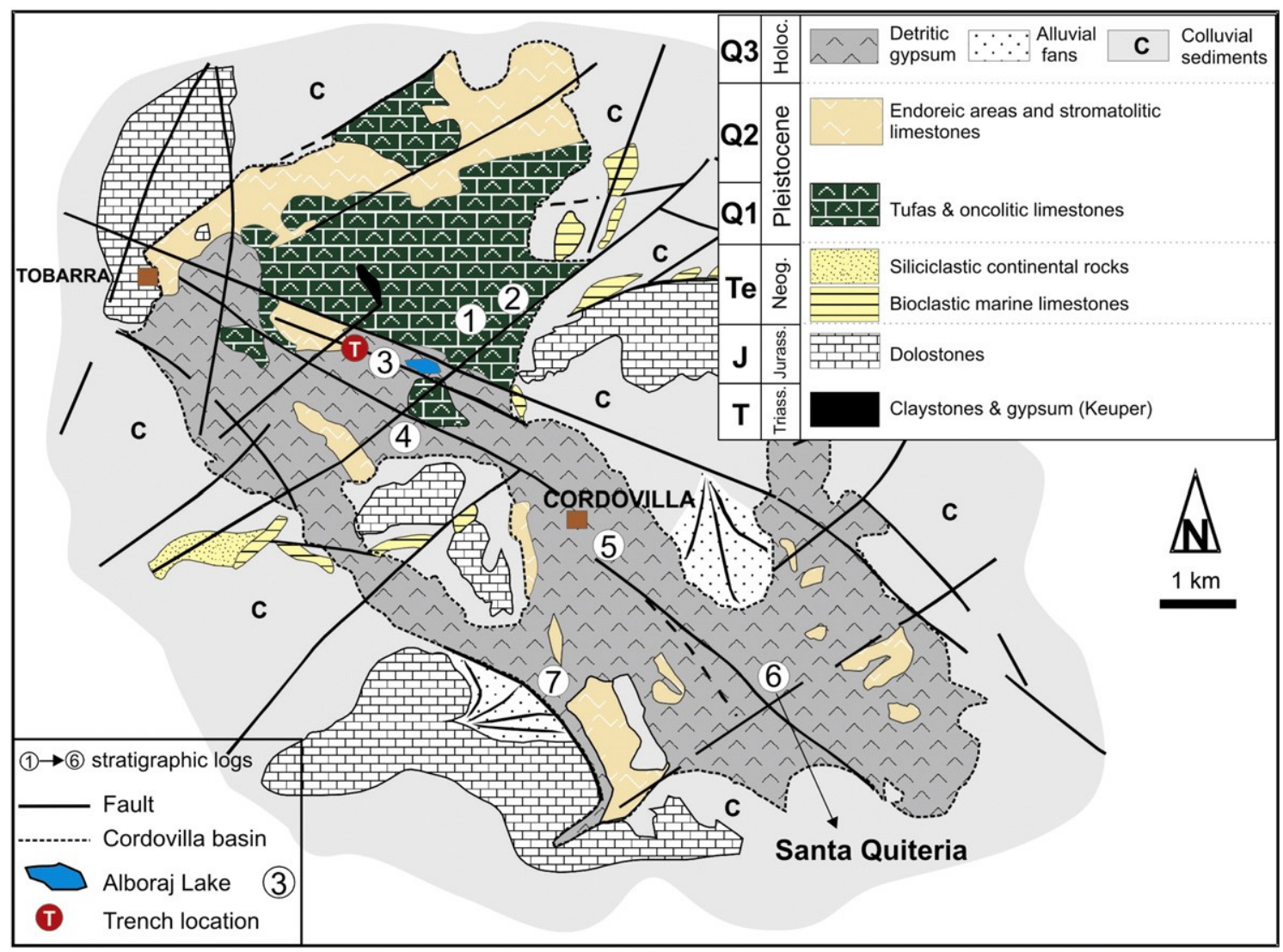

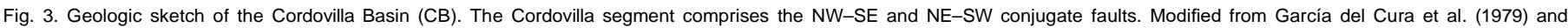

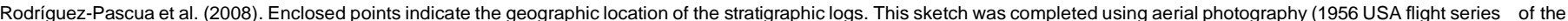
Iberian Peninsula, 1:33.000 scale) and field surveys.

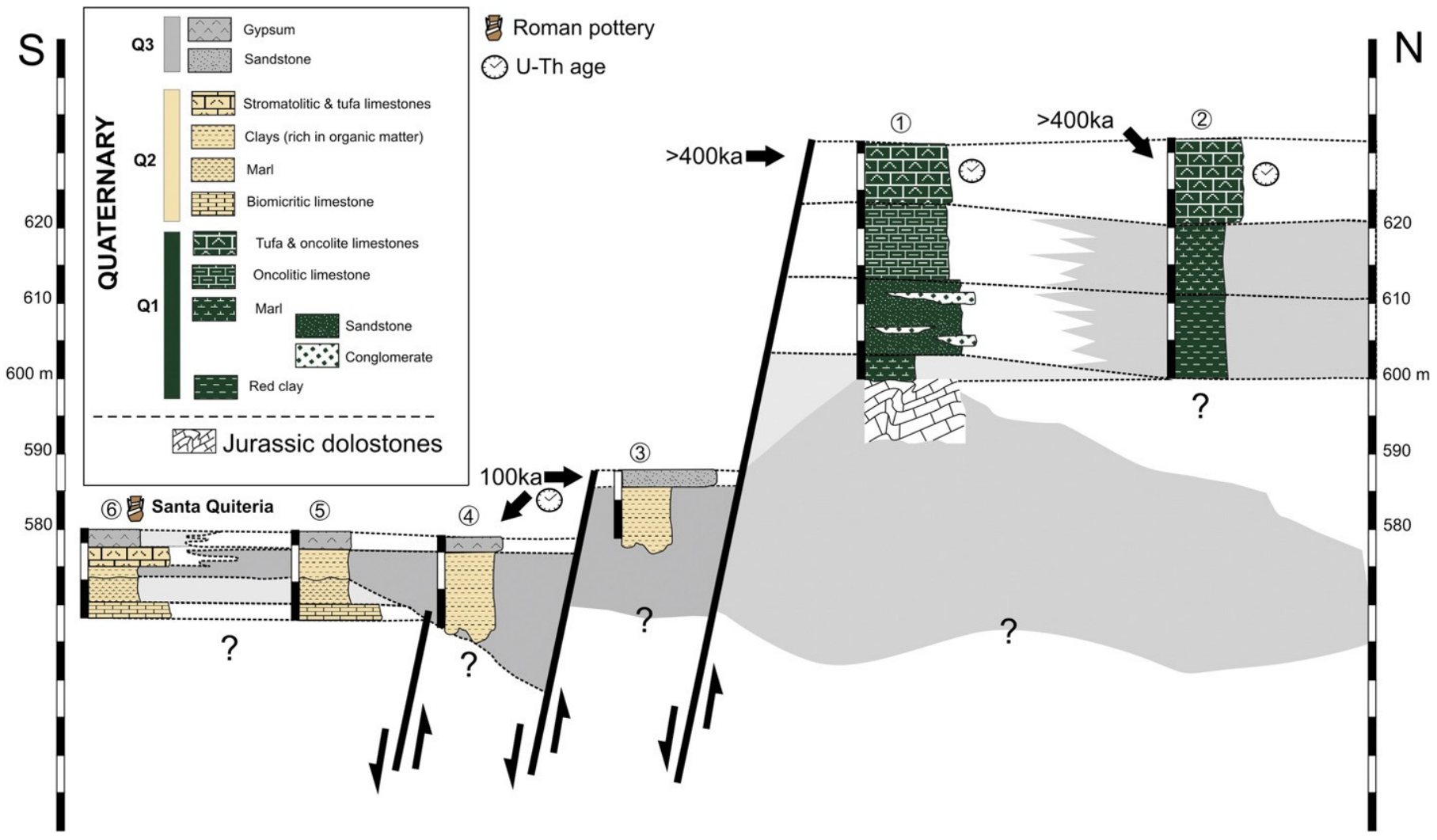

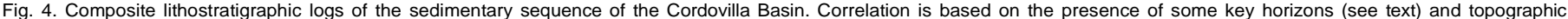
elevations (above sea level). Ages obtained by U-Th dating. The geographic location of the stratigraphic logs is indicated by encircled numbers on the geologic sketch of Fig. 3. 


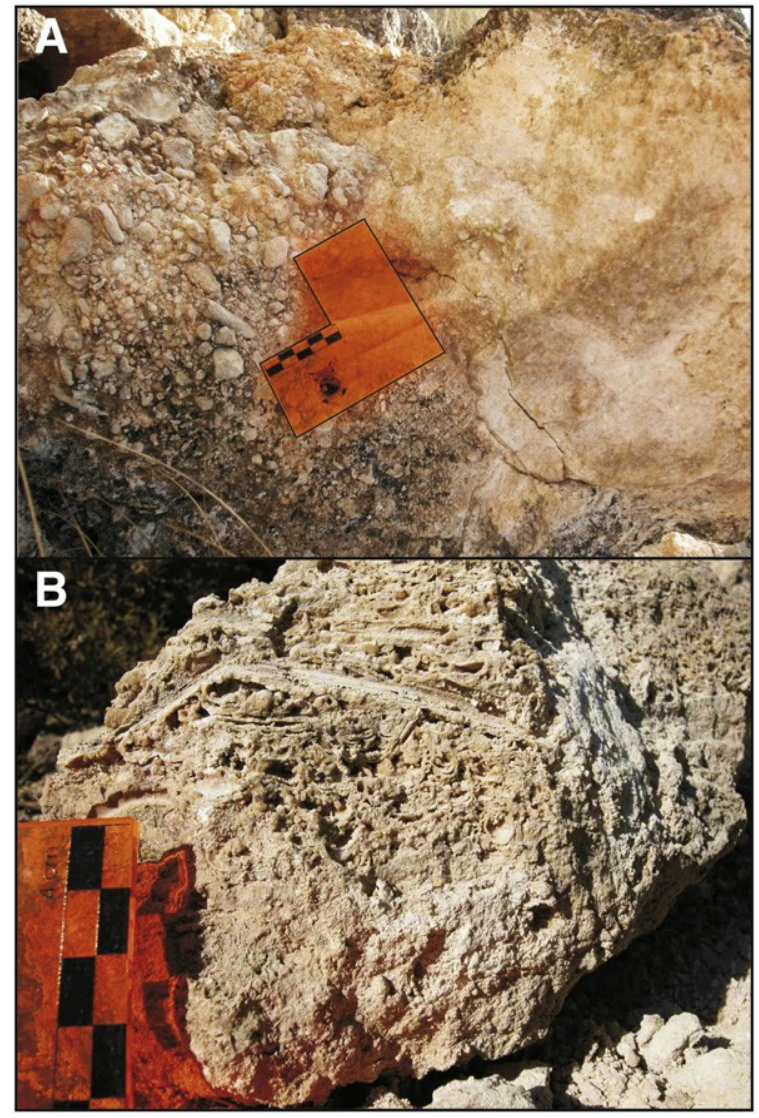

Fig. 5. (A) Micritic and oncolitic lacustrine limestone of Q1 facies. These rocks are the oldest fill of the Cordovilla Basin (U-Th dating N $400 \mathrm{ka}$ ). Scale $10 \times 10 \mathrm{~cm}$. (B) Tufa limestone (Q2) associated with the main scarp of the Cordovilla segment (Pozohondo Fault) (U-Th dating N100 ka). Scale of $4 \mathrm{~cm}$.

geomorphic (fault scarp), structural (vertical variation of similar lacustrine facies), and sedimentary (determination of energy depositional rates in relation to the seismic cycle of the Pozohondo Fault) analyses within the lacustrine basin of Cordovilla were performed. In addition, the Pleistocene sedimentary record of the active segment associated with moderate paleoearthquakes ( $5.5 \mathrm{~b} \mathrm{Mb} 6.5$ ) was studied, using trenching across the Pozohonzo Fault and stratigraphic correlations within the affected lacustrine Quaternary sequence.

\section{Lacustrine and fluvial facies at the Cordovilla Basin}

The Cordovilla Quaternary basin (CB) extends over an area of $45 \mathrm{~km}^{2}$ and it is $11 \mathrm{~km}$ in length. This basin consists of small disconnected ponds and lakes, diffuse small fluvial networks, and lake and alluvial deposits, containing a central saline pan, all of them modified by human cultivation. The geometric shape of $\mathrm{CB}$ is elongated with a principal orientation towards the NW-SE. Various extant, closed lakes are present in the central area of the basin (Alboraj Lake, Fig. 2). The landscape evolved from an alluvial plain with a fluvial network running from NE to SW to isolated endoreic areas caused from the damming of the principal fluvial channels as a result of the tectonic movement of a conjugate faults (striking towards the NW-SE and NE-SW) (Figs. 2 and 3).

In general, lacustrine sediments consist of carbonates and evaporites (Calvo et al., 1998, Fig. 3). The fault activity affected sedimentation patterns within the $\mathrm{CB}$ (Figs. 2 and 3 ).

The basement consists of a Triassic claystone diapir (Fig. 3) and Jurassic dolostones cropping out as small mountain ranges, as eroded and disconnected relict landscape.
Various isolated patches of Miocene bioclastic marine limestones and siliciclastic continental sediments border the basin as well (Calvo et al., 1998) (Fig. 3). The Miocene succession is exposed as small buttes that were quarried by the local population over the centuries (Peñas Rubias).

Six stratigraphic sections were measured and described (Fig. 4) within the $\mathrm{CB}$. Three different facies associations were identified, named Q1, Q2 and Q3 (Fig. 4). The lower facies of Q1 consists of fluvial and lacustrine sediments of almost $35 \mathrm{~m}$ thickness, consisting of red claystones at the base ( $20 \mathrm{~m}$ thick) with sandstones interbedded with conglomerate lenses (paleochannels), indicating local areas of high energy. Marlstone (inner lacustrine facies) and oncolitic limestone (shallow littoral lacustrine facies) overlie the red claystones and conglomerates (Fig. 5A). At the top of the sequence are tufa and limestone with oncolites (15 $\mathrm{m}$ thick). The oncolitic deposit (herein Q1) was reworked and exhibits imbrication of the fragments exhibiting a NE-SW direction of current flow. Facies Q1 appears at the top of a fault scarp but necessarily the top of the CB fill.

The middle facies association (Q2, Figs. 3 and 4) contains biomicritic limestones at the base, then marls, organic rich clays, and stromatolitic and tufa limestone (Fig. 5B). Q2 was measured in canal trenches at points 4, 5 and 6 (Figs. 3 and 4). The upper facies (Q3, Figs. 3 and 4) comprises detrital gypsum and sandstones. Q3 occurs only at the base of the Quaternary succession of the CB. Moreover, faulted colluvium and alluvial fans (point 7, Fig. 3) from the wasting of the Jurassic highland complete the sedimentary series. No age relationship between the colluvium and the gypsum and sandstones of Q3 can be established. At point 6 (Figs. 3 and 4) fragments of pottery (2000 BP) associated with the ancient Roman thermal baths of Santa Quiteria (Abad-Casal et al., 1998), are present at the top of Q3. At Santa Quiteria (Fig. 4) are found deposits of gypsum needles and clasts in extant channels.

The facies association of Q1 is separated from the more recent deposits of Q3 by a fault segment $1.5 \mathrm{~km}$ length and oriented towards the NW-SE. The accumulated vertical throw of this fault is almost 56 $\mathrm{m}$ and determines the present landscape of the basin.

\section{Uranium-thorium dating}

We sampled a moss-generated tufa facies (Q2) from the limestone cut by the fault on the floor of the $\mathrm{CB}$, and sampled two localities of the oncolite facies of the limestone outcropping in the upper scarp (Q1, see Figs. 3 and 4 for geographical location of samples). Three portions of the tufa sample were analysed and one each of the oncolites (Fig. 4). We used ${ }^{233} \mathrm{U}$ and ${ }^{229} \mathrm{Th}$ spikes obtained from the National Institute of Standards and Technology, and calibrated them against an elemental standard of $U$ and the Harwell Uraninite equilibrium standard, HU-1. The Daly/Faraday cross-calibration factor for the isotope dilution analyses and the mass bias corrections were determined using a natural uranium standard (NIST 4321C), and confirmed by quality control analyses of NBS U010 isotopic uranium standard.

Dates for the Q1 samples are beyond the range of the method used, and are stated as greater than $400 \mathrm{kyr}$ (Table 1). The ${ }^{234} \mathrm{U} /{ }^{238} \mathrm{U}$

Table 1

U-series analyses and derived dates from the Cordovilla Basin.

\begin{tabular}{llllll}
\hline & & & & \\
\hline Level & USGSno. & $\mathrm{U}$ ppm & ${ }^{234} \mathrm{U} /{ }^{238} \mathrm{U}$ & ${ }^{230} \mathrm{Th} /{ }^{232} \mathrm{Th}$ & Date yrs BP \\
Lower & $07-21$ & $0.73 \pm 0.02$ & $2.11 \pm 0.08$ & 160 & $119.000 \pm 825$ \\
Lower & $08-25$ & $0.98 \pm 0.01$ & $2.06 \pm 0.03$ & 220 & $107.000 \pm 2129$ \\
Lower & $08-26$ & $0.83 \pm 0.002$ & $2.10 \pm 0.03$ & 130 & $95.000 \pm 2138$ \\
Upper & $07-22$ & $0.65 \pm 0.01$ & $1.12 \pm 0.004$ & 23 & $\mathrm{~N} 400.000$ \\
\hline Upper & $07-23$ & $0.52 \pm 0.01$ & $1.15 \pm 0.004$ & 8 & $\mathrm{~N} 400.000$
\end{tabular}

The sample location appears in Fig. 4. The upper portion corresponds with the oldest sedimentary sequence of oncolitic tufa limestone. 
ratio of these samples is close to unity, supporting the old age assignment (Table 1). The three tufa samples from the lower deposits of the basin (Q2), in contrast, yield finite dates averaging close to 100 kyr (Table 1, Fig. 4, points 3 and 4). These dates are deemed viable because of the high values of ${ }^{230} \mathrm{Th} /{ }^{232} \mathrm{Th}$, the inverse indicator of detrital contamination, and the ${ }^{234} \mathrm{U} /{ }^{238} \mathrm{U}$ averaging close to 2.0 consistent with the relatively younger age assignment.

\section{Tecto-sedimentary evolution}

We have interpreted three different tectonic stages in the CB from the sediment facies (Fig. 6). The lacustrine sedimentation of the basin migrates from the NW border to the SE part of the CB in three main stages:

Stage 1 (initial stage, $>400 \mathrm{kyr}$ ): At this stage, the activity of the Pozohondo Fault created the endoreic lacustrine basin (Middle Pleistocene). This fault acted as a right-lateral breaking the surface at distances as short as $1.5 \mathrm{~km}$. Conjugate fault sets (NW-SE and NESW) bounded the whole basin (Fig. 6, Stage 1). The first deposits were clays and marls and then carbonates formed as the carbonates in the source area contributed ions into the lake. The lacustrine sequence affected by this activity is characterized by littoral oncolitic limestone (Fig. 5A), and fining-upward sandstone and clay for the offshore facies (Q1). This sequence (Q1) was reworked afterwards by fluvial systems, running down towards the SE, according to the imbrication current patterns of oncolitic fragments (NW-SE). Thus, the ancient fluvial network and the landscape were constrained by the tectonic activity of the Cordovilla segment.

Stage 2 (middle stage: 400-100 kyr): This tectonic phase corresponds to the greatest spatial extension of the active sedimentation at the basin (Fig. 6, Stage 2). The NE part of the basin (Q1) was uplifted, and the sedimentation at this point was interrupted. Close to the faulted boundaries of the basin, limestones with oncolites were deposited (Q2) concomitantly, with fluvial deposits similar to the fluvial streams of the initial stage. Silty clay enriched in organic matter and evaporitic gypsum appears in the central part of the basin. Due to this evaporitic period affecting the whole basin, the dominance of finegrained deposits can be interpreted as a result of decreasing fault activity within the basin.

Stage 3 (present stage: $100 \mathrm{kyr}$-present). In this stage, the fault ac- tivity increased and the fluvial network was truncated (Fig. 6, Stage 3), generating new endoreic basins with dammed lakes (Q3, e.g. Alboraj Lake, Fig. 2). The intense fault activity at this stage formed the present landscape as a graben basin with hydrothermal phenomena. The inner graben exhibits accumulated vertical throw of the main fault to be minimally $56 \mathrm{~m}$, separating the successions containing facies associations Q1 to Q3.

Moreover, a fault scarp with geomorphic evidence of recent ruptures was studied and related to an historic earthquake with a magnitude greater than Mw 6 (Rodríguez-Pascua et al., 2008). In this scarp, paleoseismic analysis through trenching located at the assumed latest movement of the antithetic structure of the Cordovilla segment was carried out. This fault scarp was dated at around 1100 yrs by applying the diffusion scarp model (Rodríguez-Pascua et al., 2008). Furthermore, two alluvial fans are affected by this Quaternary faulting activity (Fig. 3, point 7); however, no absolute age of this activity has been measured.

\section{Paleoseismic analysis}

A paleoseismic analysis based on a trenching development across the freshest fault scarp detected within the basin was performed. The trench was located at the fault scarp of the antithetic fault (Fig. 3, point T), close to Alboraj Lake. Geomorphic evidence from surface ruptures and the geometric shape of the scarp modelled by the erosion, suggest that this segment can be interpreted as the
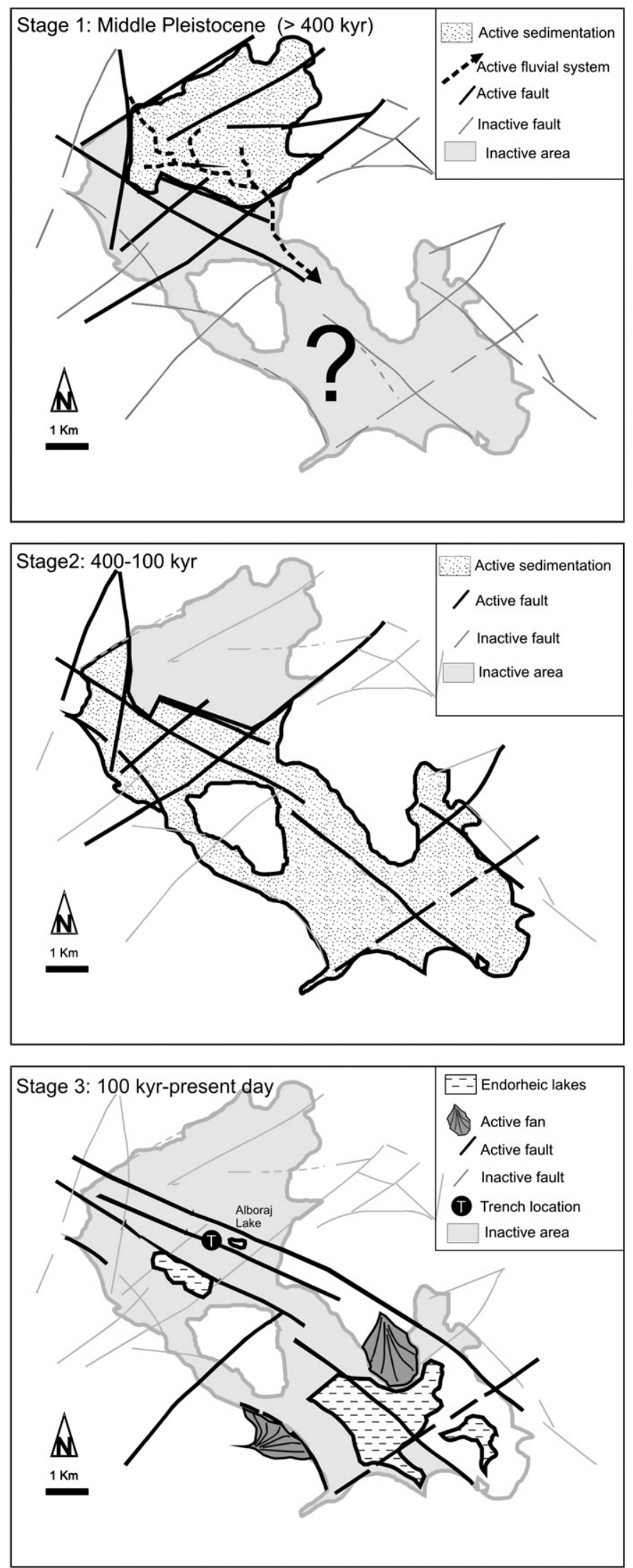

Fig. 6. Different sedimentary phases and relationships between the tectonic and the sedimentary processes that took place in the Cordovilla basin from the Middle Pleistocene to the today. Ages obtained by $\mathrm{U}-$ Th dating. See text for further explanation. 


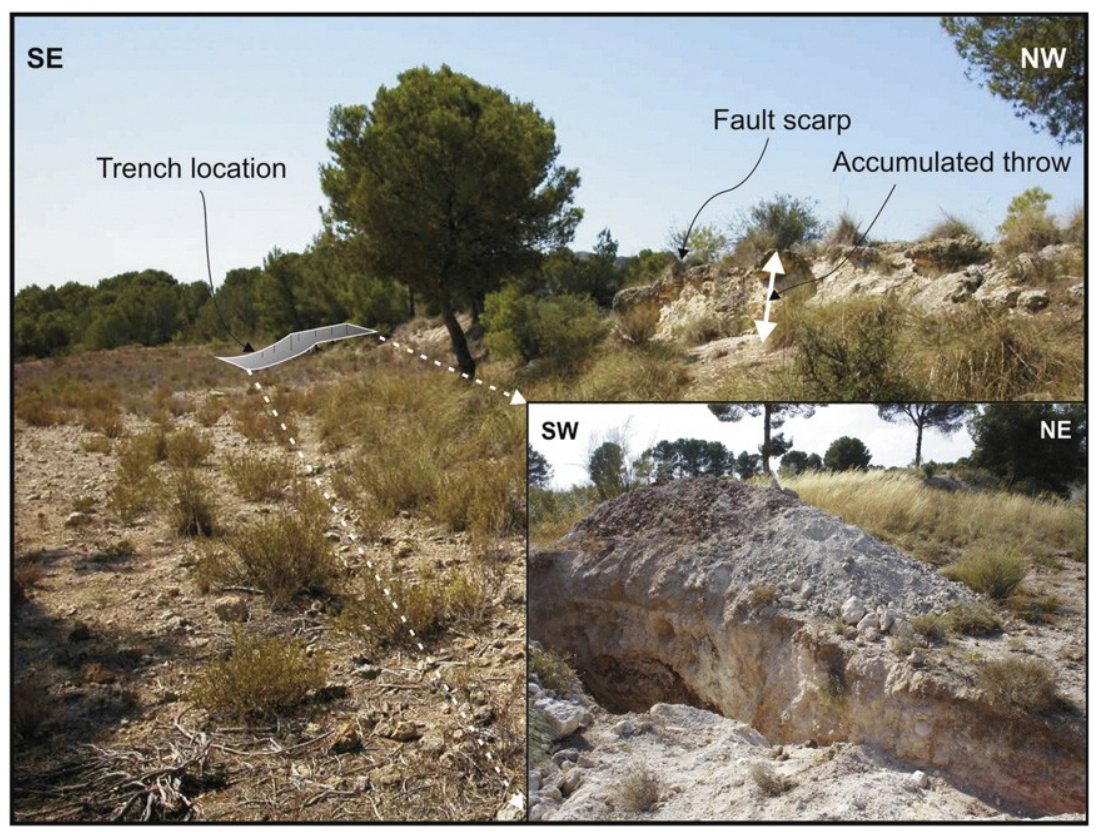

Fig. 7. Field photography of the antithetic NW-SE fault scarp interpreted as the latest movement of the Cordovilla segment and a detailed view of the trench location (see Fig. 2 for geographic location). This movement did not affect unconsolidated deposits of Q2 and Q3.

youngest movement of the Cordovilla segment. The geomorphic evidence shows a free-face scarp with a $0.75 \mathrm{~m}$ height related to open cracks, affecting poor-developed soils developed under semiarid climate conditions (Fig. 7). Several abrupt and irregular surface ruptures with striated fault planes affecting non-consoli- dated sediments of marls with gypsum occur as well (Fig.7). The selection of the precise point to perform the trenching came from the aerial photograph interpretation (ruptures affecting the young- est material), a high-quality digital elevation model, microtopo- graphic survey (rupture affecting gentle slopes of colluvium and soils interpreted from a $1 \times 1 \mathrm{~m}$ of a pixel-size digital elevation model), and field surveys performed at different surface rupture sets. We chose the fault scarp point at the assumed free-face to make a trench to identify the latest fault vertical movement $(0.75 \mathrm{~m})$, and to avoid the vertical accumulated fault throws $(1.9 \mathrm{~m}$ at the highest point of the scarp for the antithetic fault). The trench was oriented $\left(\mathrm{N}^{\circ} 0^{\circ}\right)$ perpendicular to the fault trace (NW-SE). Both sides of the trench were cleaned and examined by using a grid of $0.5 \times 0.5 \mathrm{~m}^{2}$. The log of the trench from a mosaic of photos is shown in Fig. $8 \mathrm{~A}$ and $\mathrm{B}$.

\subsection{Unit description of the trench log}

The lowest unit corresponds to the Triassic (Keuper) red claystones (Fig. 8 B; T1 and T2). It appears fractured and folded.

Unit Q1: A fluvial-lacustrine channel $30 \mathrm{~cm}$ wide shows an erosive bottom affecting the $\mathrm{T} 1$ unit and filled by reworked oncolite fragments. Unit Q2: This unit is composed of lacustrine limestones with horizontal bedding, and with scarce oncolites $60 \mathrm{~cm}$ thick. It appears as fault breccia near the fault plane. Unit Q3a is an erosive channel eroding Q2, containing sandstone with carbonate clasts. Unit Q3b is a siliceous non-consolidated, well-sorted sand $20 \mathrm{~cm}$ thick.

Unit C1: This unit contains the rocks of Q1 and Q2 that contain crack infilled with debris as well as fault breccia with $\mathrm{cm}$-sized clasts showing fault grooves. Also, within fluvial channels of Q1, imbricated oncolite fragments are present, with a pitch angle between $30^{\circ}$ and $80^{\circ}$ on the fault plane $\left(165^{\circ} / 41^{\circ} \mathrm{E}\right)$. The breccias are bounded by two secondary fault planes, deformed on the border by the Triassic claystone (T1 and T2) creep movement. Various $\mathrm{m}$-size carbonate clasts, including highly inclined and oriented oncolic limestones, are interbedded with the breccia deposits. These blocks have been interpreted as "in situ" carbonate precipita- tion by ground circulation, according to the fault plane orientation (NW-SE).

Unit S: This unit represents the present soil level (Q3s) affected by the latest fault movement (Fig. $8 \mathrm{~B}$, cells $6 \mathrm{C}$ ).

From the trench, two event horizons related to two paleoearthquakes were interpreted (Fig. $8 \mathrm{~A}$ and $\mathrm{B}$ ):

E1: Represents the oldest event-horizon showing conjugate discrete planes oriented, $164 \% 54 \mathrm{~W}$ and $004^{\circ} / 77^{\circ} \mathrm{E}$, and generating the breccia deposits of $\mathrm{C} 1$. This horizon is related to oblique-normal faults and it was deformed by creep movement of the Keuper basement ( $\mathrm{T} 1$ and $\mathrm{T} 2$ ).

E2: Represents the youngest event-horizon and is defined by strike-slip faults with a reverse component. A transpressive fault striking $120 \% 28^{\circ} \mathrm{E}$ affects the breccia deposits of C1 and Unit S (Fig. 8 A, cells $7 \mathrm{C}$ and $8 \mathrm{C}$ ).

\subsection{Paleoevents interpretation}

The event horizon E1 consists of a right-lateral movement of the Cordovilla segment, deforming the Triassic basement. E2 exhibits a positive flower structure affecting Q2 (Fig. 8 A, cell 8C) and constraining the small scarp in soils (cells 6-7-8 C). From this structure, a pure strike-slip paleoevent E3 can be suggested, although this event is not included the slip-rate estimates since more structural data are needed to corroborate this.

\section{Discussion}

We propose three different Quaternary tectonic stages at $C B$ matching the patterns of the lacustrine sedimentation, the spatialtemporal correlation of facies, and the paleoseismic analysis of the youngest interpreted fault scarp. We have applied different empirical relationships between the surface faulting rupture and the earthquake 

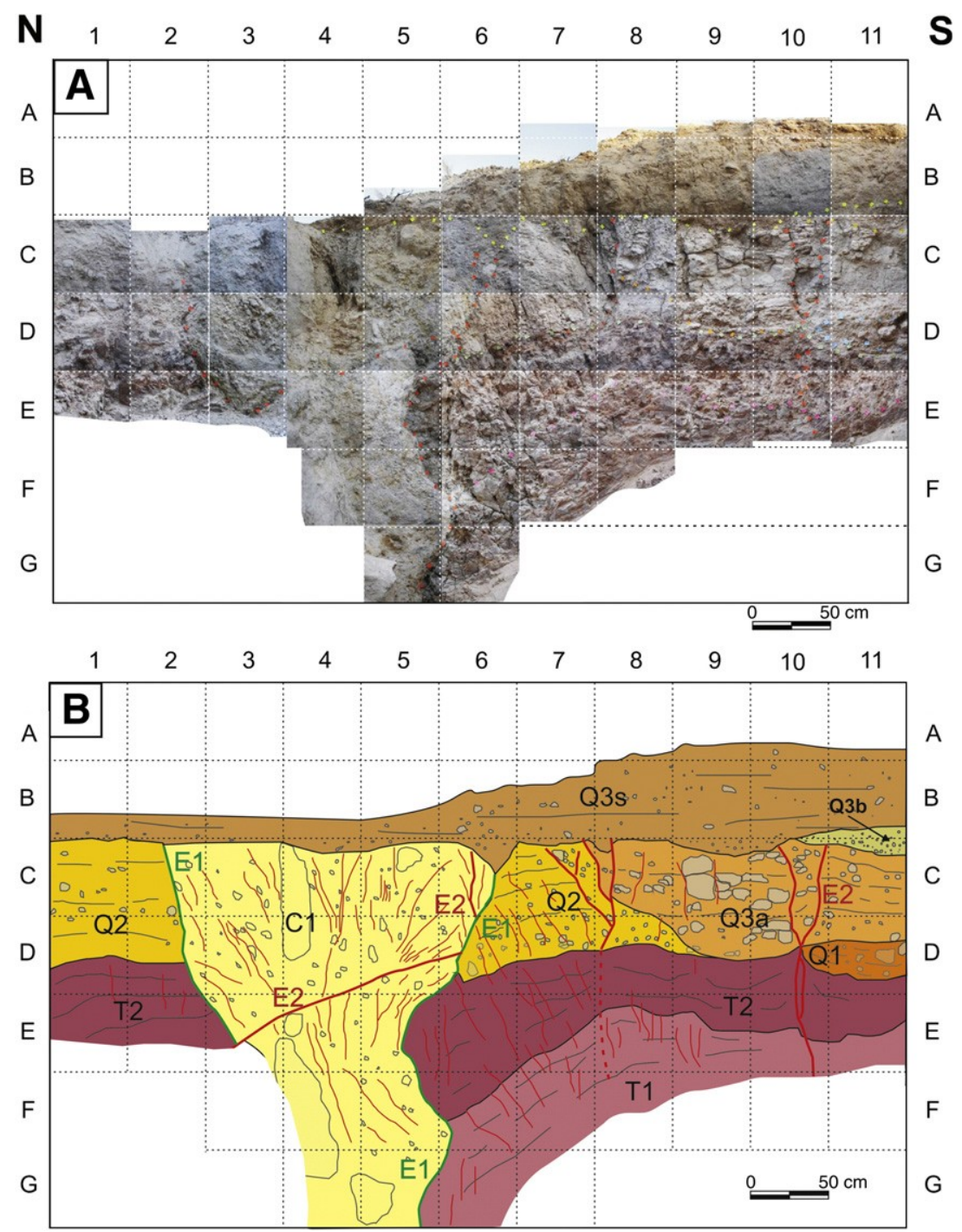

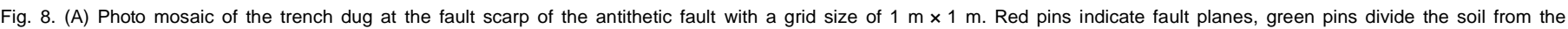

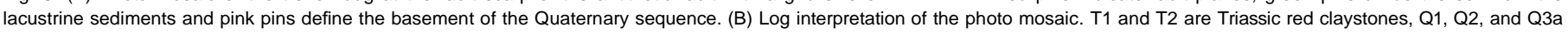

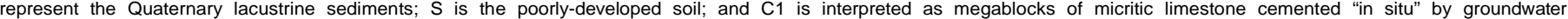

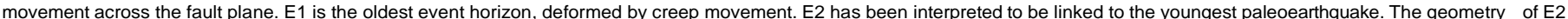

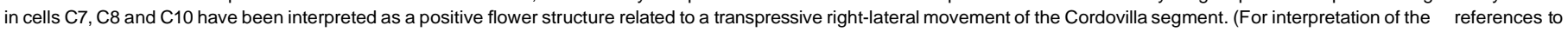
colour in this figure legend, the reader is referred to the web version of this article.)

magnitude (Wells and Coppersmith, 1994; Stirling et al., 2002), with the aim to obtain the slip rate for the Cordovilla segment (Pozohondo Fault).

\subsection{Methods for earthquake magnitude estimate}

Empirical relationships suggested by Wells and Coppersmith (1994) derived a power-law between the energy released, expressed by the magnitude $(\mathrm{Mw})$ of the earthquake, and the surface rupture length, rupture width, rupture area, and the fault displacement (maximum and average). These empirical laws were obtained from source parameters for historical earthquake worldwide (421 historical earthquakes) up to 1993, and taking into account the type of fault involved. These empirical laws give the possibility to estimate paleoearthquake size from co-seismic ruptures and fault displacements from geologic and paleoseismologic data.

According to the geometry of the Cordovilla segment, the equation proposed by Wells and Coppersmith is used for the magnitude (Mw) as a function of the surface rupture length ( $S R L)$, and is applied to strike-slip faults:

$M w=a+b^{\star} \log (S R L)$

Where $a=5.16$ and $b=1.12$, being relevant for earthquake magnitude values ranging between 5.6 and 8.1 , and a rate length/width $(\mathrm{km})$ from 1.3 to 432. Furthermore, the equation for the fault displacement (D) is expressed as:

$M w=a+b^{\star} \log (D)$

In Eq. (2), $a=6.81$ and $b=0.78$ for the maximum fault displacement (MD) at the same intervals of magnitude and displacement ranges from $0.1 \mathrm{~m}$ to $14.6 \mathrm{~m}$, for strike-slips as well.

Additionally, the empirical laws suggested by Stirling et al. (2002) to obtain the moment magnitude (Mw) associated with the surface rupture length $(\mathrm{km})$ are used. The improvement of these authors incorporates pre-instrumental data for the source parameters of the 
database, instead of the historic dataset used by Wells and Coppersmith (1994). Moreover, these authors increase the dataset from 77 datapoints of Wells and Coppersmith (1994) to 167 points, using surface rupture length, among others parameters. The equation is similar to Eq. (1) but with different value for the parameters: $a=5.45$ and $b=0.95$ for instrumental earthquakes and 5.89 and 0.79 for preinstrumental earthquakes. The interval of earthquake magnitude ranges between 4.6 to 8.1 for instrumental data sources and 6.2 to 8.2 for pre-instrumental data sources.

\subsection{Application of empirical laws for the paleoseismic database}

A summary of the magnitude estimation for two interpreted paleoearthquakes from the trench is summarized in Table 2, assuming the surface rupture length (SRL) value for each tectonic stage $(1,2$ and 3 ) is from the direct measurement of the maximum single fault shown in Fig. 6. The trench exhibits a maximum vertical throw of $0.75 \mathrm{~m}$ which has been interpreted as the latest vertical displacement affecting the topmost soils. Besides, Rodríguez-Pascua et al. (2008) have estimated a maximum fault surface rupture (SRL) of $8 \mathrm{~km}$ length and with a maximum fault displacement of $1.9 \mathrm{~m}$.

Fig. 4 shows a value of accumulated vertical displacement of ca. 9 $\mathrm{m}$ (logs 3 and 4) during the last $100 \mathrm{kyr}$ and therefore, the slip rate (SRt) for the Cordovilla segment is as far as $0.09 \mathrm{~mm} / \mathrm{yr}$ during stage 3 . Assuming this segment (12 km length) is a total co-seismic rupture, the magnitude estimated ranges between 6.4 and 6.7 (Table 2), depending on the applied regression parameters (Wells and Coppersmith, 1994; Stirling et al., 2002). Assuming that the event horizon E2 had a vertical displacement of $0.75 \mathrm{~m}$, the earthquake size obtained by the regression using Wells and Coppersmith (1994) is 6.7, and could be close to M7 from Rodríguez-Pascua et al. (2008) value of $1.9 \mathrm{~m}$ (Table 2).

Therefore, at least two earthquakes (E1 and E2) took place with a magnitude ranging between 6.4 and 7 (Table 2). Moreover, we have obtained the recurrence interval for these paleoearthquakes of $10 \mathrm{kyr}(6$ b Mb 7) and a fault slip (SRt) of $0.09 \mathrm{~mm} / \mathrm{yr}$ by plotting these values along the Slemons (1982) curve (Fig. 9).

During stage 2 , the vertical displacement obtained from Fig. 4 is ca. 16 $\mathrm{m}$. This means that during stage 2, the SRt for the Cordovilla segment was $0.05 \mathrm{~mm} / \mathrm{yr}$. This decrease in the tectonic slip rate could explain the dynamics of the sedimentation with larger and probably deeper lacustrine areas developed throughout stage 3 . The recurrence period for earthquakes with M6.5 is increased to $20 \mathrm{kyr}$ (Fig. 9), using the same parameters as that in stage 1.

Finally, during stage 1 , the accumulated vertical displacement has a minimum value of $56 \mathrm{~m}$ (Fig. 4). The presence of lake plains and tufas

Table 2

Age and magnitude (Mw) values for the interpreted paleoearthquakes.

\begin{tabular}{|c|c|c|c|c|c|c|c|}
\hline $\begin{array}{l}\text { Tectonic } \\
\text { stage }\end{array}$ & $\begin{array}{l}\text { Age } \\
\text { (kyrs) }\end{array}$ & $\mathrm{SRL}(\mathrm{km})$ & $\mathrm{D}(\mathrm{m})$ & $\begin{array}{l}\text { Mw } \\
\text { (WC) }\end{array}$ & $\begin{array}{l}\text { Mw } \\
\text { St02 }\end{array}$ & Reg type & Source \\
\hline Stage 1 & $700 ?-400$ & 8.8 & & 6.2 & $\begin{array}{l}6.3 \\
6.6\end{array}$ & $\begin{array}{l}\text { INST } \\
\text { PRE-INST }\end{array}$ & This work \\
\hline Stage 2 & $400-100$ & 6 & & 6.0 & $\begin{array}{l}6.2 \\
6.5\end{array}$ & $\begin{array}{l}\text { INST } \\
\text { PRE-INST }\end{array}$ & This work \\
\hline Stage 3 & b100 & 12 & & 6.4 & $\begin{array}{l}6.5 \\
6.7\end{array}$ & $\begin{array}{l}\text { INST } \\
\text { PRE-INST }\end{array}$ & This work \\
\hline & & 8 & & 6.2 & $\begin{array}{l}6.3 \\
6.6\end{array}$ & $\begin{array}{l}\text { INST } \\
\text { PRE-INST }\end{array}$ & Rod08 \\
\hline E2 & $1 \mathrm{~b} t \mathrm{~b} 10$ & & $\begin{array}{l}1.9 \\
0.75\end{array}$ & $\begin{array}{l}7.0 \\
6.7\end{array}$ & & & $\begin{array}{l}\text { Rod08 } \\
\text { This work }\end{array}$ \\
\hline
\end{tabular}

"Reg. type" refers to the regression equation used in this work. INST is for instrumental earthquakes, PRE-INST for preinstrumental earthquakes, and WC for Wells and Coppersmith (1994) regressions. St02 refers to Stirling et al. (2002), and Rod08 refers to Rodríguez-Pascua et al. (2008). SRL = surface rupture length, $D=$ fault displacement and, E2 = event horizon 2.

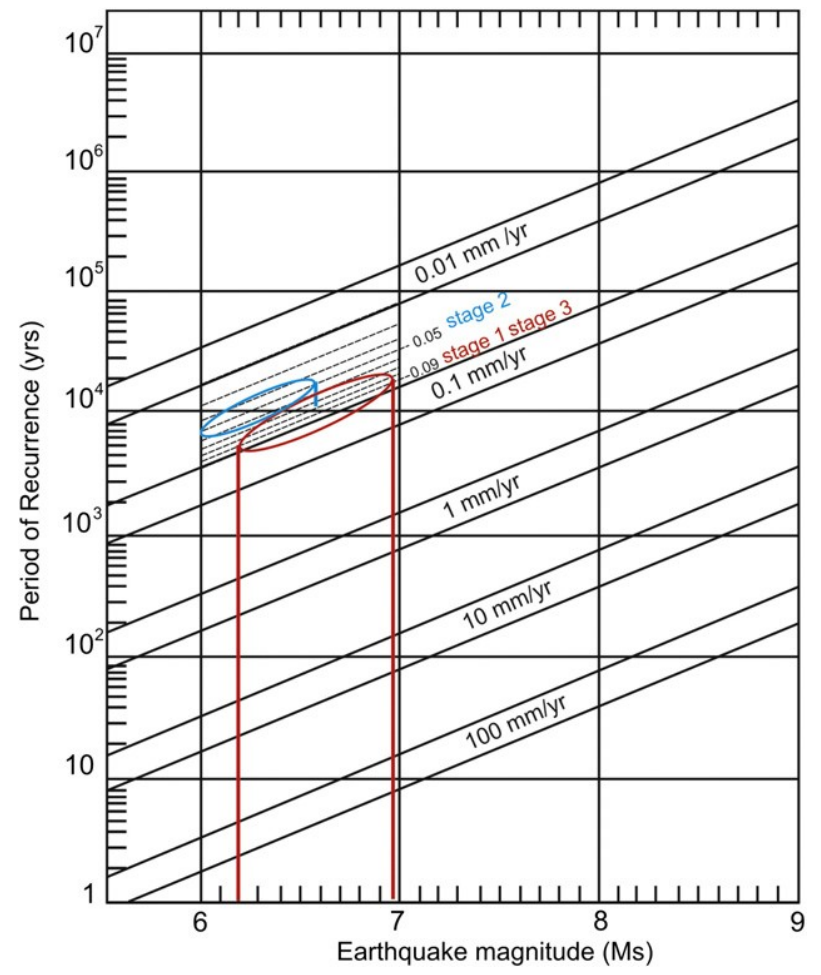

Fig. 9. Plot of earthquake magnitude vs recurrence time interval for tectonic slip rates ranging between 0.01 and $100 \mathrm{~mm} / \mathrm{yr}$. Both the stages 1 as and 3 present a greater value of SRt than stage 2. Modified from Slemons (1982). See text for further explanation.

suggest a value of SRt greater that those calculated for stage 2 in the $\mathrm{CB}$. Therefore, the oldest deposits of the basin can be as young as $1.12 \mathrm{Ma}$ (Middle Pleistocene), if a slip rate $0.05<\mathrm{SRt}<0.09 \mathrm{~mm} / \mathrm{yr}$ is assumed.

\section{Conclusions}

The Cordovilla Basin represents a good example of the tectonosedimentary relationships that allow reconstruction of the Quaternary paleoseismic history and tectonic slipping rate within an intraplate area of the Iberian Peninsula The Pozohondo Fault represents a rightlateral oblique fault oriented NW-SE with a fault trace of ca. of $55 \mathrm{~km}$ affecting both Mesozoic as Cenozoic materials, including recent Quaternary deposits (Middle Pleistocene to present). The Quaternary activity of this fault is determined from the closed lake conditions resulting from a dammed fluvial network, fresh fault scarps and surface ruptures, paleoseismic trenching, and U-series dating.

Three different lacustrine sedimentary phases have been identified and the results suggest three different tectonic stages deduced from the Cordovilla segment. Stage 1 began in the Middle Pleistocene (between 700 and $400 \mathrm{kyrs}$, U-series age), with a tectonic slip-rate as far as $0.09 \mathrm{~mm} / \mathrm{yr}$. Stage 2 was dated between $400 \mathrm{kyr}$ and $100 \mathrm{kyr}$, with the largest geographic extent of the lacustrine sedimentation. However, the slip rate for this stage decreased to $0.05 \mathrm{~mm} / \mathrm{yr}$. During stage 3 (100 kyr to present), two paleoseismic events are interpreted to have occurred before $100 \mathrm{kyr}$ (U-series age) from the antithetic fault scarp of the Cordovilla segment. Magnitudes (Mw) estimated by using the regression equations of Wells and Coppersmith (1994) and Stirling et al. (2002) range between 6.2 and 7 . The recurrence time interval from earthquakes ranges between M6.2 and M6.9 is $10 \mathrm{kyr}$. This value agrees with the deformation rate assigned to the Iberian Peninsula tectonic microplate from the instrumental seismicity and within the tectonic framework of the African and Eurasian plates with the Atlantic mid-ocean ridge (Stitch et al., 2003). From these results, 
the Cordovilla segment of the Pozohondo Fault clearly exhibits episodic activity from the Middle Pleistocene to the present. This episodic activity is defined with different values of the slip rate ranging between $0.05 \mathrm{~mm} / \mathrm{yr}$ to $0.09 \mathrm{~mm} / \mathrm{yr}$. This difference suggests that the slip rate for an active fault within an intraplate area could vary throughout time, and the short-term slip rate value could be different than long-term values for the same active segment.

\section{Acknowledgments}

We are strongly indebted to Dr. Concha Arenas, Dr. Klaus Reicherter, and Dr. Elisabeth Gierlowski-Kordesch for their constructive comments and remarks, with the aim to improve this work. We wish to thank Dr. Ana Alonso Zarza for her kind invitation to the 4th International Limnogeology Congress at Barcelona. This work was supported by the Spanish Ministry of Science and Innovation $(\mathrm{MCl})$, through the project ACTISIS (CGL2006-05001/BTE), and part of the results are included in the projectTECTO2(CGL2006-28134-E/CLI).

\section{References}

Abad-Casal, L, Gutiérrez-Lloret, S, Sanz-Gamo, R, 1998 .El Tolmo de Minateda, una historia de tres mil quinientos años. Junta de Comunidades de Castilla - La Mancha. Toledo. 161 p. (In Spanish).

Calvo, J.P., Rodríguez-Pascua, M.A., Martín-Velázquez, S., Ximénez, S., De Vicente, G. 1998. Microdeformation of lacustrine laminite sequences. An interpretation of loop-bedding. Sedimentology 45, 279-292.

Carrillo, E., Beck, C., Audemard, F., Moreno, E., Ollarves, R., 2008. Late Quaternary climatic and seismo-tectonic controls on the sedimentation in Lake Mucubaji (Mérida Andes, Venezuela). Paleogeography, Paleoclimatology, Paleoecology 259, 284-300 sp. iss. in Lake systems: sedimentary archives of climate change and tectonics.

García del Cura, M.A., Ordóñez, S., Calvo, J.P., 1979. Estudio sedimentológico de la cuenca Cuaternaria de Cordovilla (Provincia de Albacete. In: Zaragoza, CSIC (Ed.), Actas de la
III Reunión Nacional del Grupo Español de Trabajo del Cuaternario, pp. 247-257. In Spanish.

Israde-Alcántara, I., Garduño-Monroy, V.H., Fisher, C.T., Pollard, H.P., Rodríguez-Pascua, M.A., 2005. Lake level change, climate, and the impact of natural events: the role of seismic and volcanic events in the formation of the Lake Patzcuaro Basin, Michoacan, Mexico. Quaternary International. 135 (1), 35-46.

Jérez-Mir, L., 1973. Geología de la zona Prebética en la transversal de Elche de la Sierra y sectores adyacentes (provs. De Albacete y Murcia). Ph. D. Thesis, Universidad de Granada. 157 p. (In Spanish).

Martínez-Díaz, J.J., Masana, E., Hernández-Enrile, J.L., Santanach, P., 2003. Effects of the paleoseismic activity of an oblique slip fault on the morphology and sedimentology of an alluvial fan (Alhama de Murcia fault, Betic Cordillera-Spain). Annals of Geophysics. 46 (5), 775-793.

McCalpin, J.P., 1996. Paleoseismology. Academic Press, San Diego. 588 p.

Rodriguez dela Torre, F., 1990. Iberian Seismic Catalogue 1851-1900. A revision. In: Roca, A., Mayer-Rosa, D. (Eds.), Proc. XXII ESC General Assembly and activity report 19881990, Barcelona, I, pp. 317-322. 17-22 September.

Rodríguez-Pascua, M.A., De Vicente, G., Calvo, J.P., Pérez-López, R., 2003. Similarities between recent seismic activity and paleoseismites during the Late Miocene in the external Betic belt (Spain): relationship by "b" value and the fractal dimension. Journal of Structural Geology 25, 749-763.

Rodríguez-Pascua, M.A., Pérez-López, R., Calvo, J.P., García del Cura, M.A., 2008. Recent seismogenic fault activity in a Late Quaternary closed-lake graben basin (Albacete, SE Spain). Geomorphology. doi:10.1016/j.geomorph.2007.06.023.

Sanz de Galdeano, C., Vera, J.A., 1992. Stratigraphic record and palaeogeographical context of the Neogene basins in the Betic Cordillera, Spain. Basin Research 4, 21-36. Schnellmann, M., Anselmetti, F.S., Giardini, D., McKenzie, J.A., Ward, S.N., 2002. Prehistoric earthquake history revealed by lacustrine slump deposits. Geology 30 (12), 1131-1134.

Slemons, D.B., 1982. Determination of design earthquake magnitudes for microzonation. Proceedings of the $3 \mathrm{rd}$ International Earthquake Microzonation Conference. Seatle,Washington, pp. 119-130.

Stitch, D., Ammon, C.J., Morales, J., 2003. Moment tensor solutions for small and moderate earthquakes in the Ibero-Maghreb region. Journal of Geophysical Research 108, 2148. doi:10.1029/2002JB002057.

Stirling, M., Rhoades, D., Berryman, K.R., 2002. Comparison of earthquake scaling relations derived from data of the Instrumental and Preinstrumental Era. Bulletin of the Seismological Society of America 92 (2), 812-830.

Wells, D.L., Coppersmith, K.J., 1994. New empirical relationships among magnitude, rupture length, rupture width, rupture area, and surface displacement. Bulletin of the Seismological Society of America 84 (4), 974-1002. 